\title{
Conversations with Epistemologies of Feminism: A Systematic Review
}

\author{
Dr. Onoriode Collins Potokri \\ Department of Educational Leadership and Management, \\ University of South Africa (Unisa), Pretoria, South Africa \\ potokc@unisa.ac.za OR cnuvie@gmail.com
}

\section{Doi:10.5901/mjss.2014.v5n1p353}

\begin{abstract}
This article provides comprehensive and summarised insights to the epistemologies of feminism. It is an exploratory research, which used epistemological theory; and a methodological analysis embedded in the system approach theory of literature review as its theoretical foundation. Reviewing the literature as a means of researching could be problematic following the scanty, irrelevant and at times voluminous materials available to researchers. On account of this a content analysis research method was used. Among its revelations, this article reveals that feminism theorists seek to understand how political and social relations of gender have shaped our understanding of challenges, desires and anticipations of women, not only in the present and in limited capacity but also to understand how we ought to know and how we can improve our knowledge practices. Also, feminist theories provide justifications for the study of feminism and the need for linking the subject to other fields of inquiry given its links, for example, to capitalism and socialism as alluded to by Marxists and radical theorists respectively.
\end{abstract}

Keywords: feminism; feminist theories; epistemological theories; exploratory research; and content analysis

\section{Introduction}

In this article, existing and relevant literature on feminism and feminist theories was reviewed in an attempt to reasonably or intricately understand the epistemologies of this fast emerging field of feminism. In the course of reviewing, I came to the conclusion that there was a need for a well-researched text or piece that built on the classical contributions of earlier writers while incorporating the more recent and diverse literature around the world. Although a number of classical theoretical works devoted to the field of feminism exist, I nevertheless felt that there was a dearth of simplified material or text available and appropriate for novice scholars and students, as well as newcomers to the field of feminism. It is in the light of this that I conceived the idea of researching an explanatory yet scientific article. In specific terms, this article seeks to provide comprehensive and summarised insights into the epistemologies of feminism.

\section{Theoretical Foundation}

The theoretical foundation of this article was built on two sets of theories, namely, epistemological theory, that is, beliefs about knowledge and knowing and their relations to learning (Hofer and Pintrich, 1997), and a methodological analysis embedded in a systems approach theory of literature review (Levy and Ellis, 2006). The former underpins the discussions and conclusions of this article while the latter informs the choice of methodology adopted.

Epistemology is an area of philosophy concerned with the nature and justification of human knowledge (Hofer and Pintrich, 1997; Babbie and Mouton, 1998). A growing area of interest for educators and researchers is that of personal epistemological development and epistemological beliefs: how individuals come to know, the theories and beliefs they hold about knowing and the manner in which such epistemological premises form part of and influence the cognitive processes of thinking and reasoning (Hofer and Pintrich, 1997). The views of Hofer and Pintrich align with the purpose of this article - provision of comprehensive and summarised insights into the epistemologies of feminism for novice scholars or newcomers to the field of feminism. Achieving this is tantamount to the epistemological beliefs of the researcher (myself) and the personal epistemological development of the targeted audience of this article (novice scholars or newcomers to the field of feminism).

Epistemological theories are concerned about how knowledge is constructed, how knowledge is understood and how knowledge is evaluated, an essential frame for the relevancy of literature review (Levy and Ellis, 2006). Epistemological theories mirror conceptual understanding of how personal epistemology relates to learning and 
education, derivable from specific ontological and theoretical assumptions. Three general views exist: first, epistemology is developmental, that is, development is the aim of education (Kohlberg and Mayer, 1972) and thus part of the goal of education is to foster epistemological development (King and Kitchener, 1994; Perry, 1970). Second, epistemology exists in the form of beliefs, and learning is influenced by the epistemological beliefs that individuals hold (Ryan, 1984; Schommer, 1990). Third, epistemology is either similar to theory (Hofer and Pintrich, 1997; Hofer, 1994) or exists as more fine-grained epistemological resources and, in the process of learning, such theories and resources are activated and engaged in ways that are context-dependent (Hammer and Elby, 2002). Theories in general challenge, replace or extend our understanding of what is going on among the members of a society (Charles Taylor, 1985; Babbie and Mouton, 1998).

These views imply different outcomes of interest in the knowledge-making process and development. Epistemological development is the outcome variable, often seen as indicative of broader intellectual development (Hofer and Pintrich, 1997). Further to this, the outcome might be learning and knowledge construction, influenced by epistemological resources and theories that have been activated in the process at a metacognitive or meta-knowing level (Hofer and Pintrich, 1997; Hofer, 1994). This leads us to consider the empirical evidence for the relationships between epistemology and learning. These views further support the need for or relationship between epistemological beliefs of the researcher (myself) and personal epistemological development of the targeted audience of this article or the researched.

Hofer and Pintrich note that different research programmes have pursued varying definitions and conceptual frameworks and used quite different methodologies to examine an individual's epistemological beliefs and thinking. Fink (2010) articulates that literature review is a unique and acceptable means of understanding knowledge because only when knowledge is understood then can it be constructed and evaluated to fit into the social world in terms of practical usage and meanings.

A systems approach to conducting an effective literature review ensures the validity and reliability of a study, as well as the conclusions, by making use of quality literature to serve as the foundation for research (Barnes, 2005). Straub (1989) notes that with validated instruments, researchers can measure the same research constructs in the same way, granting improved measurement of independent and dependent variables and in the long run, helping to relieve the confoundment that plagues many streams of phenomena. Given this, it is worthwhile to accept literature on feminism and feminist theories as the instrument for this research. For this reason, Ngai and Wat's (2002) suggestion that quality research instruments are needed for both empirical and theoretical research is upheld.

The use of a methodological analysis, a component of system approach that underpins quality research instruments, enables researchers to better explain as well as understand problems and solutions that address actual issues that newcomers or practitioners to a field of study or concept are struggling with (Webster and Watson, 2002). A systems approach using an effective literature review helps to provide a firm foundation to the selection of the methodology for a study (Ngai and Wat, 2002). This, to me, is a justification for the use of methodological analysis in systems approach, as Levy and Ellis (2006) emphasise. The selection of the methodology should not be interpreted as placing more rigour on one type of research such as qualitative, quantitative, exploratory or confirmatory, but rather it should enable the researcher to understand what methodologies were previously validated (Straub, 1989); hence, motivating the choice of the researcher according to what is considered most suitable for a research (Levy and Ellis, 2006). In the light of this, qualitative content analysis was embraced.

\section{Methodology}

The purpose of this article as mentioned earlier was to provide comprehensive and summarised insights into epistemologies of feminism through simplified materials for novice scholars and newcomers to the field of feminism. Relying on a systematic review (literature reviewing), an exploratory research design was adopted.

For Bless and Higson-Smith (1995, 42), the purpose of exploratory studies is to gain insight into a phenomenon or situation. Given options associated with this design or method, I chose to use content analysis. Content analysis is a qualitative research technique that has been applied to a variety of data and to various depths of interpretation (see SCodeberg and Lundman, 2001; Berg and Welander Hansson, 2000). Further to this, Fink (2010) and Booth (2012), recommend content analysis for researching or reviewing the literature. The traditional approach to content analysis was specifically employed. This approach entails gathering together all that can be found and to summarise, in narrative style, the studies and the key points arising from the literature (Graneheim and Lundman, 2004).

As earlier indicated in the theoretical foundation section, a traditional systems approach to conducting an effective 
literature review ensures the validity and reliability of the study and perhaps conclusions by making use of quality literature to serve as the instrument for research (Barnes, 2005). The approach assisted me to shorten or drastically reduce the voluminous literature while still retaining the meaning of the whole reviewed (Graneheim and Lundman, 2004). In the course of collecting data, that is, reviewing the literature, I concentrated on secondary data only, research publications in journals, conferences proceedings, articles and books because of their rich empirical depth, credibility and authenticity.

\section{Literature: Systematic Review}

\subsection{Introduction}

A literature review is a systematic, explicit and reproducible method for identifying, evaluating and interpreting the existing body of recorded work produced by researchers, scholars and practitioners (Fink, 2010). Literatures are among the most imperishable possessions of humanity and knowledge of them is essentially necessary for research. As Fouché and Delport $(2005,123)$ note, a review of the literature is aimed at contributing towards a clearer understanding of the nature and meaning of the problem that has been identified. With regard to this article, the problem identified is linked to comprehensive and summarised epistemologies - knowledge of feminism and feminist theories for novice scholars or newcomers to the field of feminism.

\subsection{Feminism}

According to my understanding following the reviewed literature, feminism as a field of study began as a fundamental critique of the social world underpinning the ignorance of women's life situation and with men's dominance as its central focus. Feminism draws on different theoretical and pragmatic orientations, different national contexts and dynamic developments (Olesen, 2005). Despite the variations in theoretical orientation, context and development as Olesen noted, feminist theorists and scholars alike see gender as a basic organising principle that shapes the conditions of women's lives (Lather, 1991). For Alcoff and Potter (1992), feminism is a field of study that encompass sets of knowledge and realities analysed in a normative yet scientific manner.

Harding (1991) asserts that feminism originated in "eighteenth century England" as a social movement that promoted equality between the sexes and as a system of thought that challenged mainstream science. It spread to other parts of the world and has been critiqued from various perspectives and in particular as part of the colonisation of knowledge in the third world aided by the methods of social anthropology (Parpart, 1996).

The origins of feminism are diverse - ranging from resistance to oppressive practices in the third world, to struggles for equality in the first world (Alcoff and Potter, 1992; Friedman, Metelerkamp and Posel 1987, 3). Friedman and others (1987) stress further that while women have fought on their own behalf for centuries all over the world, feminism as a political movement really developed in the twentieth century. Importantly, feminism has been influenced by socialist thought and practice and anti-imperialist and nationalist struggles in the third world. Ussher $(1999,99)$ writes that feminist scholars or researchers focus on a "critical analysis of gender relationships in research and theory ... and recognition of the need for social change to improve the lives of women". This I believe is a methodological means of listening to the voices of women and attempting to respond in a way that will navigate their lives towards prosperity.

As Endeley and Ngaling (2007) note, the word 'feminism' elicits resentment, fear and worry in many people, especially men. In their words, it is dreaded by those who benefit from unequal power relations, but it can be acceptable to groups that suffer from subordination, oppression, discrimination and inequality. Support for feminism is not restricted to women only, nor men. However, few men supported feminism at the outset. Then, it was not unusual for those who supported feminism to suggest a different appellation for feminist ideologies, principles and practices (ibid 74). In agreement, Ogunyemi $(1996,122)$ notes that the masculinity critic dismisses the women who criticise society as "women palava" (troublemakers) because they are making visible that (the woman) which was invisible: expressing the pain that was swallowed in silence, imbuing with pride that which is female and therefore considered contemptible. From my readings, I now know that feminism is becoming an increasingly accepted part of ordinary social and political discourse, even if it is not viewed in the same light by everyone (Beasley, 1999), therefore, it is safe to claim that feminism does not have a universal definition.

The 1960s saw the rise of movements for the liberation of women in every country in the West. Equally, the 1960s was a "time of prosperity in the West yet a time when young people, especially women, challenged the capitalist value 
they found around them - values such as competition, inequality and consumerism" (Friedman et al. 1987, 4). Friedman et al. (1987) further assert that they not only challenged the exploitative aspect of capitalist society, that is, aspects which led to wealth on the one hand and poverty on the other, but they also challenged associated characteristics of the capitalist society in which they lived, including racism and imperialist foreign policy. At that time (1960s) capitalism was undergoing transformations which affected women's roles generally. Capitalism, as noticed by concerned scholars and reported by Marx (1859), significantly affected the role of women in the labour force. As revealed by the literature, before the 1960s, during the Second World War, women were enticed into wage labour but at the end of the war they were encouraged to go back into the home to make way for men returning from the war front.

The post-war period mirrored and emphasised feminised domestication, women as consumers, motherhood. The return of many women to the home after the Second World War created a new identity for women who were known and identified as working class. This created tension between the reality of women's lives and the ideal image of family life. This tension caused women to think and question their lives especially when they examined women's lives in the era prior to the Second World War, during the Second World War and after the Second World War. The actual genesis or springboard of the feminist movement can therefore be said to have been in the thinking and questioning about women's lives and experiences. Also, it is the zeal to correct both the invisibility and distortion of female experience in ways relevant to ending women's unequal social position (Lather 1991, 71).

\subsection{Types of feminist theories:}

There are many feminist theories (see Alcoff and Potter, 1992). These theories are mainly categorised according to the beliefs of theorists, that is, feminist theorists. Among these theorists only three: liberal, Marxist and radical feminist theories are critically engaged or dwelt on in this article given that they are the founding theorists or theories upon which others have been built or have evolved.

\subsubsection{Liberal feminist theorists}

Liberal feminist theorists are among the forerunners of the gender equality movement. Such theorists emphasise equal opportunities for women before the law. Ritzer and Goodman (2003) define liberal feminism as a feminist theory of inequality that proposes that women may claim equality with men on the basis of an essential human capacity for reasoned moral agency. Molyneaux $(2000,11)$ writes "for the liberal feminist, the ideal gender arrangement has tended to be the one in which an individual acting as a free and moral agent chooses the life most suitable for him or her ... a liberal feminist has always had a reformist orientation". In most nation states, the liberal feminist position has been used as a framework for creating machinery and government departments that promote gender equality within the capitalist socioeconomic system (Connelly, Tania and MacDonald 2000, 41; IGWS 2004, 25). Liberal feminists argue that the liberation of women consists of their freedom to choose their lives, to be able to compete with men on equal terms in the professional and political worlds and in the labour market. Liberal feminists are interested in seeing to the elimination of any constraint that could jeopardise the liberation of women. Liberal feminists claim that women, like men, are endowed with reason and that their capacity, therefore, to choose has the same worth as that of men, but the problem is that there are constraints in society which discriminate against women solely on the basis of their sex and so prevent the exercising of that free choice. Liberal feminists support the equality of men and women through political and legal reforms (see Ritzer and Goodman, 2003; Mabatha, 2011). Building on this, they work for the eradication of institutional bias and the implementation of better laws.

Although it has been scholastically acknowledged that capitalism as a means of creating wealth on the one hand and poverty on the other accounts for one of the reasons for inequalities among men and women, men not women were encouraged and allowed to own property as well as to dominate the labour force. Despite this, liberal feminists do not condemn capitalism. As a way of disassociating themselves from seeing women as inferior liberal feminists, believe that capitalism or a capital system provides the opportunities for the realisation of choice of any person including women who makes the necessary effort (Jayawardena, 1986). However, they admit that women will have to try harder than men. The equality that liberal feminists clamour for is not equality of strength and myth between men and women nor achievement equality, but equality of opportunities and in the basic necessities of life. Besides the non-condemnation of capitalism, liberal feminists do not also believe in job stereotypes, that is, the belief that certain kinds of jobs are designated for women and others for men. For example, housework for women and other jobs, considered to be white collar and prestigious, for men, such as engineering, medicine and so on. They believe that women can do these so-called 
prestigious jobs if equal opportunities in this regard are given to both men and women. With regards to jobs outside the home, liberal feminists suggest that women will achieve the same results on the job as men, if they are prepared to commit themselves to the job and, equally, leave their problems behind at home as men tend to do.

Apart from being among the forerunners of the gender equality movement, the liberal feminist theorists were equally at the forefront of creating Women in Development (WID) (Connelly 2000, 42). WID was informed by the liberal modernisation paradigm which promoted individual rights, freedom of choice and equality of opportunities for men and women (Gordon 1996, 13). The WID accepted capitalism as a panacea for women's inequality without questioning it. However, its position with regards to WID is not without criticism and limitations. For instance, social researchers from Africa criticised it for not accommodating adequately the African context where pre-capitalist formations did not promote women and development. Socialist feminists, on the other hand, criticised it for contributing to the production of a cheap labour force in its uncritical acceptance of capitalism (Gordon 1996, 16). Moreover, WID has been criticised because it has been influenced by the modernisation paradigm, which does not apply to all contexts, and the fact that it is limited to the economic level and does not include the social aspects of inequality (Parpart, Connelly and Barriteeau 2000, 57; Mannathoko 1999, 450).

Besides the WID, there are other feminist approaches or positions such as the WAD (Women and Development) Agenda, the GAD (Gender and Development), Gender Mainstreaming and many others that emerged as attempts to further understand the experiences of women and to better their lives. Given the criticisms and limitations of the liberal feminist position, some feminists sought answers for a more nuanced theory in Marxism for women's development, because it had developed a thorough critique of liberalism and capitalism.

\subsubsection{Marxist feminist theorists}

Marxist theorists are believed to have emanated from the ideologies of Marx, who lived from 1818 to 1883. Marx and his collaborator and friend, Engel, as well as other Marxist theorists are referred to as revolutionary theorists. They aimed at not just understanding the world but at changing it (Nobel 2000, 71). Marx (1859) never paid much attention to the question of gender. He was "concerned to describe and analyse contemporary western society", which was purely a capitalist society. Marx's real problem was not with people but with the exploitation that comes with capitalism. In his view, the distinguishing feature of capitalist society was the division and conflict between capitalists on the one hand and the working class on the other. Furthermore, he maintained that the relationship between the two was one of exploitation and struggle. One point he emphasised was the existence of exploitation in all class societies, but under capitalism exploitation was hidden rather than obvious. In agreement with the views of Marx, Jayawardena (1986) asserts that in current capitalist societies people are exploited as slaves or through other forceful means, whereas under capitalism the worker offers himself or herself freely as a wage labourer.

As the number of followers of Marxist ideology grew, so did the number of women among them. Some of these women saw the need to relate the ideas of Marx to the predicaments and challenges of women specifically and with respect to their understanding of women's exploitation by capitalists. These women and some men who are of the same school of thought are regarded as Marxist feminists. For them, women's freedom is not an individual but a social achievement that societies seriously need. On account of this, Marxist feminists opine that social freedom can be realised only in societies where work is adequately organised, where no individual(s) can control the conditions of others' lives and where people can develop their talent and human potential through freedom to work. Accordingly, some Marxist feminists demanded a socialist society.

Subsequently, these Marxist feminists, sometimes referred to as traditional Marxists, argued that everything would be better under socialism and that to avoid struggle against men would divert energy from the class struggle (Nobel, 2000). They further articulate that eradication of the class struggle would transform people's lives, and result in an egalitarian society where equality for all prevails. Classical Marxists hold that within capitalist society, women were subjected to a special form of oppression, rooted in the sexual division of labour, because of their primary responsibility for the household and childcare, women were condemned to seclusion in the home. This exclusion from public life and particularly the workplace meant that they were excluded from participating in collective action to change their own lives as members of the working class. In conclusion, Marxists' primary position on women and gender inequalities was that they were due to capitalist forms of domination, where oppression and gender equality are achieved with the demise of the capitalist system. However, according to Connelly and others $(2000,45)$, this approach did not fully address the concerns of women as it placed the elimination of capitalism as a prerequisite for women's liberation. A broad spectrum of the literature on feminism and gender reveals that the dissatisfaction with both liberal and Marxist strands of feminism 
led to the emergence of radical feminism.

\subsubsection{Radical feminist theorists}

Radical feminists are primarily interested in the 'root cause' of women's oppression. They posit that all forms of domination evolved from the oppression of women. Therefore, they argue that the oppression of women should be a central issue and concern to individuals and societies. Their justification is that individuals cannot live in isolation, but live together as a group or in families within societies that are governed through legislative means and common resources. Benokraitis $(2005,37)$ discloses that the radical feminist movement considers male domination to be a major cause of women's inequality. By contrast, Mbatha $(2011,31)$ writes that "radical feminists like liberal feminists argue that women's power is removed from them". Similarly, Ritzer and Goodman (2003) write that theories of gender oppression go further than theories of gender difference and gender inequality by arguing that not only are women different from or unequal to men, they are actively oppressed, subordinated and even abused by men. This translates into male dominance and women's inferior status, making it difficult for them to protect themselves against what they dislike (Rashid, 2006).

Radical feminists advanced the idea that patriarchal domination is the process that hindered women from development and suggest separate projects for women, thus protecting them from being integrated into the patriarchal world (ibid 125). In this kind of feminism, individual oppression or domination of women is equated with and seen as both a social and a political problem. For instance, Friedman et al.'s 1987 book, What is feminism?, states that if many individual women are experiencing certain kinds of domination in their personal relationships, it could not simply be their own individual problems but rather that it had to be a broader social and political issue. In the light of this, they suggest that every facet of the personal experience of women is perceived as political by radical feminists. Based on the fundamental concerns and beliefs of radical feminists, as revealed by the large and diverse body of theoretical, methodological and pedagogical literature that has been generated in the last three decades, it is now common to hear feminists and other gender scholars describe radical feminists as a group of feminists that focus on the patriarchy as the social system which functions in hierarchical and dominating ways, such that individual women are subordinate to individual men. For this reason, and epistemic injustice (see Grasswick, 2004; Grasswick, and Webb, 2002), radical feminists often react in anger by 'whipping up' their argument for support against women's oppression. Their anger is usually directed at men, who they see as embodying the patriarchal power relations of the entire societal system (Jagger, 1985).

Radical feminists challenge women to revalue themselves, redefine themselves and re-socialise themselves. Furthermore, they challenge women to train or bring up their children, boys and girls, in a way that will help them resist and distance themselves from oppression.

\section{Discussion}

Although no universal definition is given for feminism, but drawing on the writings of scholars above, feminism is a field of inquiry that is mainly concerned with diverse situations of women and the institutions that influence them in terms of support or influence against their situations. Many of the significant contributors to the field of feminism have been feminist theorists who challenge mainstream science and investigate the role of feminism knowledge production and feminism development/history. Motivated by the political project of eliminating the oppression of women, feminist theorists are interested in how the norms and practices of knowledge production affect the lives of women and are implicated in systems of oppression and liberation. To do this, feminist scholars, both women and men, in their various contributions uphold the welfare of women as second to none, citing it absence as a catalyst to the wellbeing of any society. On account of this, feminist theorists seek to understand how political and social relations of gender have shaped our understanding of the challenges, desires and anticipations of women, not only in the present and in limited capacity, but also to understand how we ought to know and how we can improve our knowledge practices. Also, feminist theorists provide justifications for the study of feminism and the need for linking the subject to other fields of study given its links, for example, to capitalism and socialism as alluded to by Marxists and radical theorists respectively.

Feminist theorists have increasingly attended to the interrelations between gender and other social categories such as class and their significance for knowledge, particularly as it affects the lives of women. In different ways the liberal, radical and Marxist feminist theorists argued. Those who argue that there are epistemically valuable feminine ways of knowing integral to women, without providing a social analysis, could also be viewed as resisting certain elements of a social epistemology (Grasswick, 2004; Grasswick, and Webb, 2002). 
Nevertheless, by far the majority of work in gender and women-related studies or issues can be adequately understood through feminism. Therefore, on the one hand, feminism represents more than a small subset of knowledge and realities and, on the other hand, it provides a normative yet scientific analysis of knowing. In summary, the reviewed literature illuminates, while underpinning, the importance of feminist theories in framing theoretical concepts and background for understanding the social dimensions of knowing about the social world since women complete human existence.

\section{Conclusion}

That I choose to summarise the epistemologies of feminism for novice scholars, perhaps newcomers, to the field of feminism through feminist theories literature sits well with the general views of epistemological theories as Hofer and Pintrich (1997) underpin, particularly the third view - that epistemology is either theory like or exists as more fine-grained epistemological resources and in the process of learning such theories and resources are activated and engaged in ways that are context-dependent (Hammer and Elby, 2002). Here, context-dependent refers to feminism, a field of study. It is evident in this article, that much know about feminism is known through the literature in relation to feminist theories that emanated from the beliefs of feminist theorists. This suggests what I would like to refer to as an epistemological chain: beliefs lead to learning and learning leads to knowledge. To sum up, literature in general and theories in particular, being means of knowing are powerful tools that articulate how meanings about feminism are constructed and evaluated particularly as it concerns the institutions that supports or militate against the welfare and aspirations of women and men, but specifically women.

\section{References}

Journals

Berg, A. \& Welander Hansson, U. (2000). Dementia care nurses' experiences of systematic clinical group supervision and supervised planned nursing care. Journal of Nursing Management 8(6), 357-368.

Connelly, P, Tania Li, J. \& MacDonald, M. (2000). Feminism and development: theoretical perspectives in Jane Parpart, Patricia Connelly and Eudine Bariteau (eds). Theoretical Perspectives on Gender and Development. International Development Research Centre Ottawa: 51-160.

Endeley, J.B.M \& Ngaling, M.N. (2007). Challenging gender inequality in higher education: Attitudes and perceptions of teaching staff and administrators at the University of Buea, Cameroon. In Feminist Africa, Rethinking Universities. Issue 9: 63-84.

Friedman, M., Metelerkamp, J. \& Posel, R. (1987). What is feminism? Agenda: a Journal about Women and Gender. No1, 3-24.

Grasswick, H.E \& Webb, M.O. (2002). "Feminist Epistemology as Social Epistemology," Social Epistemology: A Journal of Knowledge, Culture and Policy, 16(3): 185-196.

Grasswick, H.E. (2004). "Individuals-in-Communities: The Search for a Feminist Model of Epistemic Subjects," Hypatia: A Journal of Feminist Philosophy, 19(3): 85-120.

Graneheim, U.H \& Lundman, B. (2004). Qualitative content analysis in nursing research: concepts, procedures and measures to achieve trustworthiness. Nurse Education Today. 24, 105-112.

Hofer, B.K \& Pintrich, P.R (1997). The development of epistemological theories: beliefs about knowledge and knowing and their relation to learning. Review of educational research. Spring, 67(1): 88-140.

Levy, Y. and Ellis, T.J (2006). A system approach to conduct an effective literature in support of information systems research. Informing Science Journal. Vol. 9, 184-212.

Mbatha, T. (2011). In and out of polygyny: A case of black South African women's experiences of marriage. In Agenda: empowering women for gender equity. 87/25(1): 29 - 37

Mannathoko, C. (1999). Theoretical perspective on gender in education: the case of Eastern and Southern Africa. International Review of Education, Vol.45, No. 4/5.

Parpart, J. (1996). 'Rethinking gender, race and identity in a global context', Gender and Development in Africa, Vol. 1(1):1-6

Rashid, S.B. (2006). 'Small powers: contextualising reproductive and sexual rights in slums in Bangladesh', in IDS Bulletin 37(5).

Ryan, MP. (1984). Monitoring text comprehension: individual differences in epistemological standards. Journal of Educational Psychology 76(2):249-258.

Schommer, M. (1990). Effects of beliefs about the nature of knowledge on comprehension. Journal of Educational Psychology 82: 498504.

Schommer, M. \& Walker, K. (1995). Are epistemological beliefs similar across domains? Journal of Educational Psychology, 87(3):424432.

SCoderberg, S. \& Lundman, B (2001). Transitions experienced by women with fibromyalgia. Health Care for Women International 22 (7):617-631. 
Straub, D.W. (1989). Validating instruments in MIS research. MIS Quarterly, 13(2):147-170.

Webster, J. \& Watson, R.T. (2002). Analyzing the past to prepare for the future: writing a literature review. MIS Quarterly, 26(2):13-23.

\section{Books}

Alcoff, L. \& Potter, E. (1992). Feminist epistemologies. New York: Routledge.

Babbie, E. \& Mouton, J. (1998). The practice of social research. Cape Town: Oxford.

Beasley, C. (1999). What is feminism? An introduction to feminist theory. Crow's Nest, NSW: Allen and Unwin.

Benokraitis, N.V. (2005). Marriages and families: changes, choices and constraints (5th ed). Upper Saddle River, NJ: Pearson Prentice Hall.

Bless, C. \& Higson-Smith, C. (1995). Fundamentals of social research methods. Cape Town: Juta

Booth, A. (2012). Systematic approaches to a successful literature review. Sheffield: Sage

Fink, A. (2010). Conducting research literature reviews: from internet to paper. Los Angeles: Sage

Gordon, P. (1996). Transforming capitalism and patriarchy: gender and development in Africa. Boulder, CO: Lynne Riennar.

Harding, S. (1991). Whose science? Whose knowledge? Thinking from women's lives. Ithaca: Cornell.

Jagger, A. (1985). Feminist politics and human nature. Wilmington, CA.

Jayawardena, K. (1986). Feminism and nationalism in the Third World. Zed Press, London.

King, P.M and Kitchener, K.S. (1994). Developing reflective judgment: Understanding and promoting intellectual growth and critical thinking in adolescents and adults. San Francisco: Jossey-Bass.

Lather, P. (1991). Getting smart: feminist research and pedagogy with/in the post-modern. New York: Longman.

Marx, K. (1859). Contribution to the critique of political economy (Lawrence and Wishart: 1971 edn).

Marx, K \& Engels, F. (1846). The German ideology (Lawrence and Wishart: 1970 edn).

Marx, K \& Engels, F. (1848). The communist manifesto (Penguin Books: 1967 edn).

Noble, T. (2000). Social theory and social change. New York: Palgrave.

Ogunyemi, C. (1996). African Wo/man Palava: The Nigerian novel by women. Chicago: The University of Chicago Press.

Parpart, J, Connelly, M, \& Barriteau, V. (2000). Theoretical perspectives on gender and development. Ottawa: International Development Research Centre.

Perry, W.G. (1970). Forms of intellectual and ethical development in the college years: A scheme. New York: Holt, Rinehart and Winston.

Taylor, C. (1985). Philosophy and the human sciences. Cambridge: Cambridge University Press.

\section{Sections in edited books}

Fouché, C.B. \& Delport, C.S.L. (2005). In-depth review of literature. In De Vos, H. Strydom, C.B Fouche \& CSL Delport (eds). Grassroots research for social sciences and human service professions. 3rd edition Pretoria:Van Schaik

Hammer, D.M \& Elby, A. (2002). On the form of a personal epistemology. In BK. Hofer \& PR. Pintrich (eds.), Personal epistemology: the psychology of beliefs about knowledge and knowing (169-190). Mahwah, NJ: Lawrence Erlbaum.

Olesen, V. (2005). Early millennial feminist qualitative research: challenges and contours. In NK. Denzin \& YS. Lincoln (eds), The Sage handbook of qualitative research (3rd ed) 235-278. Thousand Oaks: Sage.

Ussher, J. (1999). "Feminist approaches to qualitative health research," in M. Murray and K. Chamberlain (eds), Qualitative health psychology: theories and methods. London: Sage.

\section{Reports and papers}

Hofer, B. (1994). Epistemological beliefs and first-year college students: motivation and cognition in different instructional contexts. Paper presented at the annual meeting of the American Psychological Association, Los Angeles.

Institute for Women and Gender Studies. (2004). Annual Report. University of Pretoria, Pretoria.

\section{Web source}

Ritzer, G. \& Goodman, D. (2003). Sociological theory. McGraw-Hill Higher Education, available at http://highered.mcgrawhill.com/sites/0072817186/student_view0/chapter13/chapter_su accessed on 5th May 2011 